\title{
The Pandemic That Has Forced Teachers to Go Online. Zooming in on Tips for Online Teaching
}

\author{
Teun J. de Vries ${ }^{1,2 *}$ \\ ${ }^{1}$ Amsterdam University College. University of Amsterdam and Vrije Universiteit Amsterdam, Amsterdam, Netherlands, \\ ${ }^{2}$ Department of Periodontology, Academic Centre for Dentistry Amsterdam, University of Amsterdam and Vrije Universiteit \\ Amsterdam, Amsterdam, Netherlands
}

Keywords: online teaching, molecular cell biology, undergraduate medical education, student involvement, pandemic restrictions

\section{INTRODUCTION}

The COVID-19 pandemic has forced an immediate worldwide transition from frontal teaching in classrooms and lecture theaters to online-teaching on various video conference platforms. Because of its suddenness, little framework or guidelines existed for online teaching. It is important to think about how to create the common ground of a classroom that enables open dialogue, that encourages students and that creates a safe learning environment. Here, I describe my own quest in online teaching in a course of Molecular Cell Biology for undergraduates. It has been a search on what works best, and how to adapt to the new style of teaching compared to in-class teaching. The new era requires lenience from teachers and an openness to learn from the younger generation. They may teach $u s$ on their experience with an online environment.

The COVID-19 pandemic has tremendously affected the way of teaching as it suddenly switched from an in-person to an online format. How immense and sudden this transition has been, is illustrated in a recent survey among 1,400 American colleges. The two colleges that reported to go fully online on the 6th of March 2020 were followed by all remaining colleges within the same month (Marsicano et al., 2020). Although online teaching has been among us since the start of internet during the early 1990's and its success has been reviewed (Martin et al., 2020), the above figures on the sudden implementation indicate that the world-wide teacher community had to implement online methods at short notice. Surveys on teacher preparedness confirm the low level of preparedness at the beginning of the pandemic (Scherer et al., 2021). In this paper, I will describe the choices I have made when it became apparent in August 2020 that all teaching had to go online for the entire first term, from September until December 2020. I have been teaching a theoretical course of Molecular Cell Biology to two groups of 25 students for the past 5 years at Amsterdam University College (AUC), $4 \mathrm{~h}$ a week per group. AUC is an international liberal arts and sciences college, all classes are English taught (De Vries et al., 2019). My classes regularly contain at least ten nationalities. AUC classes are more interactive than regular lectures and also focus on student engagement in the conversation. My course is aimed at second-year students and is part of the pre-medical track, using chapters from the broadly used Essential Cell Biology (Alberts et al., 2019). Below, I describe what it meant in terms of infrastructure of the course and how I tried to build a classroom environment. Next, I describe the essence of continuous evaluation by students and teachers when going online and finally I acknowledge the new possibilities of online teaching.

\section{Confronted With Going Online}

Though classes went straight online from early March 2020 onwards, quite a bit of uncertainty prevailed during summer 2020, when COVID-19 figures dropped severely in the Netherlands and across Europe. In August, it became apparent that three teaching variants would be installed at AUC: (1) in-class teaching to the whole group, allowing classes of $\sim 12$ students per classroom; (2) a mixed variant, or hybrid teaching, where 
the teacher could choose to have 12 students in-class and the others online; and (3) a fully online course. On top of that, AUC had to comply with $20 \%$ of the maximal occupancy of the building, to allow for enough ventilation and enough space between those inside. First-year classes were prioritized to be in the building when possible, given the necessity of bonding between the newly arrived students. Given the fact that my class was for second year students, I decided from that point onwards to go $100 \%$ online.

The choice to go online and the enduring pandemic affected teaching in multiple ways, the first of which was my course program. For instance, I was not able to organize a lab excursion designated to learn some pipetting skills, since we had to obey the governmental restrictions at my lab. Instead, I planned five meet-the-teacher-sessions, which I was able to host during the largest part of the semester in small groups at a time with the $1.5 \mathrm{~m}$ distancing discipline. This was my only opportunity to physically see my students. In hindsight, this provided a necessary opportunity to escape the $2 \mathrm{D}$-images I had from my students, making them more complete characters, with their individual peculiarities. I thoroughly enjoyed these sessions which were scheduled after the three exams and for essays as feedback opportunities.

Apart from these COVID-19 affected arrangements, I had set an important additional teaching goal for this season which I now had to implement online. I wanted to invest much more in familiarizing students with the laboratory techniques of Molecular Cell Biology. This is a sensible investment, since I discovered during previous years that this knowledge was a shortcoming of many students. It is important to know these techniques, because students have to read biomedical research articles in the late stages of the course but also in parallel courses in the Medical Track. For protein detection, I wanted students to be familiarized with immunohistochemistry, flow cytometry, Western blotting and enzyme linked immunosorbent assay (ELISA). I knew about Zoom, a popular video conference platform which has been used successfully for online teaching since March 2020. So, I designed “technique tool boxes" for each of the molecular cell biological techniques, and applied a mixture of flip the classroom (Styers et al., 2018) and jigsaw (Sanaie et al., 2019) as an educational design. Jigsaw is a teaching technique where the receiving side of teaching has to reproduce what was taught. A recent meta-analysis of flip the classroom showed that it has varied outcomes in terms of learning outcomes compared to a more frontal classroom approach, with the teacher in the lead. Success rate was higher when adding extra hours in class for it (Van Alten et al., 2019). Compared to the previous year, I allotted one extra class to achieve my learning goals on mastering the theoretical aspects of cell biological techniques. In essence, I split students into groups through breakoutrooms where together, each group had to finish an unfinished PowerPoint presentation, the toolbox, and present that next class to the whole class. I did this in the second week of the course, so that students could benefit from what was learned for their essay and presentation work, where they had to cover molecular cell biological research papers. The toolboxes were completed by the students and by putting it on the digital learning environment Canvas, students could further study it for the exam, where students had to answer questions about their own techniques and about the ones that were presented by other groups (jigsaw). This way, students made their own learning material.

When the first lessons were approaching, I had to familiarize myself fully with the online platform of Zoom with the help of my daughters in higher education and friends with whom I could practice. Nevertheless, I experienced a lot of anxiety just before the first class. Will all students log in? Is my internet connection satisfactory? How is my audibility? Most disastrous was that construction workers started working just a few houses away, 15 min before my first class. Luckily, the drilling noise was not disturbing to my audience.

\section{Mimic a Classroom Environment}

One of my goals in this unfortunate era of scarce contact, was to invest in creating a classroom setting. I did this by opening Zoom 5 min before the start of class, switching my camera off, being muted. One by one, students entered, on mute and most of the time leaving their cameras off. I started class by unmuting and by switching on the camera. After doing this, I asked everybody to switch on the camera, so that we could see each other. The first class was used to introduce us to one another. I did this in my class by choosing a favorite organelle, or mini-part of a cell. At this stage, I usually show what a future career in molecular cell biology could hold, by showing a short video of a role model. This year, inspired by the black lives matter movement and how diversity is still lacking in the higher levels of university (Barber et al., 2020), I showed a wonderful little video on Tracy Johnson, a scientist-teacher at University of California at Los Angeles (UCLA) and a role model both for teachers and students, who had just been rewarded with a prize on undergraduate teaching https://www.youtube.com/watch?v=cNu7qSag9f8. The clip of 4 min contained many wonderful quotes that students could relate to. I asked the students to write down and share quotes from the clip that appealed to them.

When sharing a presentation, it is obviously not possible to have a classroom experience, but as soon as the "stop share" was activated, all of us came back in class with cameras on. Zoom, like other platforms that are suitable for online teaching, has the pleasant feature that names of students are visible in the individual's zoom screen. For me, this was a blessing in disguise: making it much easier to learn names this year. Another aspect of mimicking a classroom is that I encouraged students to interrupt me by unmuting. This enabled students to freely ask questions and opened dialogue amongst participants, as the regular practice of raising hands was not possible on Zoom. In a class with a maximum of 25 participants, this is absolutely doable and allows each student to participate to the extent that they are comfortable with. At the end of class, I made it possible for students to linger a while if they still wished to conversate on the topics discussed in class or otherwise. Thus, a very inviting and informal atmosphere was created, with some resemblance to a classroom.

\section{Acknowledge and Verbalize the Achievements and Shortcomings of the Online Teaching}

Online teaching was relatively new for all of us and it required experiencing what works best. Right from the start, I expressed 
to the students that we are in it together, and that I am there to help students with any difficulties they might face. Feedback on how to improve was welcome at all stages of the course. This year I have developed an awareness for the students online coping ability. It is important to show compassion. One has to develop a new repertoire of what works best (Biggs and Tang, 2011; Schoenmaker et al., 2020). I very quickly abandoned the idea that I have to cover the prerequisite chapter of the book in two hours of teaching with some interactive moments. Instead, I summarized the chapter during the first hour - also providing a lot of opportunities to interact - and after a short break, I used the second hour to assign students to breakout rooms to make questions on that chapter. I then finished with a plenary session where students were in the lead, answering and debating the questions.

During a mid-term course evaluation, students further suggested to use the quiz function of Zoom as a starter of class, to engage and energize the possibly sleepy students and those students who are tired after a day of online activities. Although quizzes may not be the ideal extra preparation for exam results (Haberyan, 2003), the incorporation was functional, since it was also a way to reflect on weekly societal aspects of Molecular Cell Biology, for instance why the RNA vaccine from Moderna did not require low storage temperature, whereas the Pfizer/Biotech vaccine did.

It is also good to express what goes well in class, especially with online teaching. So, more than ever, I genuinely complimented the group when there was good group participation. It is important to acknowledge that these times with online teaching are extremely difficult. As a teacher, one should demonstrate curiosity about how the students experience online classes. Student presentations were all online as well, using shared screen, without frontal explanation in a classroom. I wanted to know whether it was more difficult or more relaxed when presenting from home, sitting in a chair. To my surprise, most students thought that this was way more relaxed.

One should foster awareness beforehand on what can go wrong during presentations. With an unreliable internet connection, students may become unnecessarily nervous and also may use more time than anticipated. As a teacher, one should be ahead of this and tell students in advance that when the internet connection does not work properly for whatever reason, it can never be held against the student and that the student has the right to re-do the presentation at a later time. I also realized that due to Covid-19, students could be sick for a while or in quarantine. So, it is also important to schedule extra time slots for presentations by students.

\section{Find and Exploit the Benefits of Online Teaching}

Not all aspects of online teaching are doom and gloom. For instance, in my course, I have always scheduled approximately four specialized guest speakers from the Amsterdam-based academic institutes. With the same effort, one can now invite specialists from all over the world! This year, I invited a friend from Brazil, who presented on his molecular cell biological work on infection models and bone degradation by osteoclasts (Souza and Lerner, 2019). For the internationally oriented students, this was not only a way to be introduced to cell biological research at work, but it also exposed them to the international opportunities and limitations of doing that in Brazil. In terms of time efficiency and planning, cost reduction and reduction in air pollution, nothing beats such a guest lecture! Less than a year ago, such an opportunity would never be even considered.

Another wonderful feature of online teaching is the possibility of using breakoutrooms. When used intelligently, one can create a relatively quiet learning environment in which the students can discuss tasks set for the specific class. This allowed for some focused work between students, and when finishing early, it also enabled informal exchange, very important in times of isolation such as during a pandemic. When compared to inclass splitting up of groups, the serenity of breakout rooms is wonderful. As teacher, one can "apparate" as J. K. Rowling's Harry Potter characters do, that is, to appear and disappear or "disapparate" in breakout rooms, just to monitor how the process is evolving. It still feels like magic. It is also fun to invent new jargon, not only with the Harry Potter analogy, but also that when I closed the breakoutrooms, I mentioned that we were back in the "general assembly."

Exams of my course were done in the old-fashioned way: open questions, written on paper with the occasional question that required drawing a schematic. In fact, the exams were a rare opportunity of seeing my students. Students sat $1.5 \mathrm{~m}$ apart, I supervised wearing a face mask. Due to COVID-19, some international students were confined to their home country due to travel restrictions. Other students were confined to their dorm rooms due to quarantine measures. I nevertheless insisted that those students would experience exactly the same exam. I used Zoom to simultaneously supervise exams all over the world. After finishing the physical exam-sit at AUC, I sent the exams $5 \mathrm{~min}$ before the exam, allowing a bit of time to print them. Through zoom, I was at one point able to simultaneously supervise exams in Canada, the United Kingdom, Latvia, France, Poland, Macedonia and Bulgaria. It gave a special sense of connectedness! After the exam, students could scan their written result as a PDF or alternatively take pictures of the exam and send them back by email.

\section{DISCUSSION}

Finally, this Opinion article on my own quest in online teaching puts the online teaching in broader perspectives. First of all: will online teaching be the future, and, specifically on courses like Molecular Cell Biology: what are the challenges when the labs remain closed?

\section{Online Teaching: the Future?}

Since the teaching community in higher education has had only one year of experience, online teaching has not been evaluated extensively. Possibly, an opinion gap exists between teachers and students whether online teaching should be continued. When Covid-19 restrictions were lifted in South Korea after a period of lockdown, allowing teaching in classrooms to resume, no 
$<84 \%$ of medical students preferred to continue class online, whereas only $14 \%$ of teachers wanted to continue this way (Kim et al., 2020). In a recent Indian survey among medical students and teachers, $54 \%$ of the students wanted online classrooms to be continued, whereas another considerable part (24\%) wanted to return to in class teaching. Teachers foresaw a mix of both traditional and online teaching in the future, and that possibly a mix of 70:30 could be ideal (Gupta et al., 2021). Whether we will ultimately embrace online teaching, remains to be seen and is likely also dependent on whether audibility and strength of internet connections. A recent survey among students and teachers in Iraq, reported increased difficulties due to COVID19 enforced online learning among $69 \%$ of students and $51 \%$ of teachers (Tuma et al., 2021). Also in the United States, a nationwide survey among pharmacology students revealed that only $30 \%$ of the students preferred blended approaches, whereas $47 \%$ explicitly wants to return to normal classes (Hamilton et al., 2020). A survey from the United Kingdom reported much higher workload for teachers, $<50 \%$ felt confident with online teaching, with the odd exception of teachers in Computer Sciences, where confidence reached 76\% (Watermeyer et al., 2021).

\section{Back to the Classroom, Back to the Laboratory}

Specifically for Molecular Cell Biology, one should refrain from training only theoreticians. At the moment, due to the long

\section{REFERENCES}

Alberts, B. D., Hopkin, K., Johnson, A., Lewis, J., Raff, M., Roberts, K., et al. (2019). Essential Cell Biology. Milton Park: Taylor and Francis. 734p.

Barber, P. H., Hayes, T. B., Johnson, T. L., and Márquez-Magaña, L. (2020). Systemic racism in higher education. Science 369. 1440-1441. doi: $10.1126 /$ science.abd7140

Biggs, J., and Tang, C. (2011). Teaching for Quality Learning at University, 4th Ed. Maidenhead: Open University Press. 389p.

De Vries, T. J., Schoenmaker, T., van Veen, H. A., Hogervorst, J., Krawczyk, P. M., Moonen, C. G. J., et al. (2019). The challenge of teaching essential immunology laboratory skills to undergraduates in one month-experience of an osteoimmunology course on TLR activation. Front Immunol. 10:1822. doi: 10.3389/fimmu.2019.01822

Delgado, T., Bhark, S.-J., and Donahue, J. (2020). Pandemic teaching: creating and teaching cell biology labs online during COVID-19. Biochem. Mol. Biol. Educ. 49, 32-37. doi: 10.1002/bmb.21482

Gupta, S., Dabas, A., Swarnim, S., and Mishra, D. (2021). Medical education during COVID-19 associated lockdown: faculty and students' perspective. Med. J. Armed Forces India 77, S79-S84. doi: 10.1016/j.mjafi.2020.1 2.008

Haberyan, K. A. (2003). Do weekly quizzes improve student performance on general biology exams? Am. Biol. Teach. 65, 110-114. doi: 10.2307/ 4451449

Hamilton, L. A., Sudab, K. J., Heidel, R. E., McDonough, S. L. K., Hunt, M. E., and Franks, A. S. (2020). The role of online learning in pharmacy education: A nationwide survey of student pharmacists. Curr. Pharm. Teach. Learn. 12, 614-625. doi: 10.1016/j.cptl.2020.01.026

Kim, J. W., Myung, S. J., Yoon, H. B., Moon, S. H., Ryu, H., and Yim, J.-J. (2020). How medical education survives and evolves during COVID-19: our experience and future direction. PLOS ONE 15:e243958. doi: 10.1371/journal.pone.0243958 lasting COVID-19 restrictions, there is a world-wide concern that a new generation of undergraduates will be delivered that will have no laboratory experience due to the restrictions that prevail. There are interesting initiatives to experience a virtual lab online, with movies showing how to pipet, with instructions on microscopy and on a lot of laboratory protocols (Delgado et al., 2020), but let us hope that this will be a temporary solution, since otherwise students will be alienated from the world of scientific discovery and innovation.

\section{AUTHOR CONTRIBUTIONS}

TV designed and wrote the manuscript. The manuscript was further slightly edited for English, structure and content by six students that followed the online course of Molecular Cell Biology.

\section{ACKNOWLEDGMENTS}

I would like to thank the students Eleanor Swanson Scott, Aada Kallio, Franka Verlaan, Helena Kissiova, Tanuj Arora, and Laura Vissers of the Molecular Cell Biology online classes who acted as superb editors for this article. They suggested, added and improved the pre-final draft, demonstrating what talents I had in this group of students.
Marsicano, C. R., Felten, K. M., Toledo, L. S. S., and Buitendorp, M. M. (2020). Davidson College Educational Studies Working Paper: Educational Studies Working Paper Series. Tracking Campus Responses to the COVID-19 Pandemic. APSA Preprints. doi: 10.33774/apsa-20203 wvrl

Martin, F., Sung, T., and Westine, C. D. (2020). A systematic review of research on online teaching and learning from 2009 to 2018. Comput. Educ. 159:104009. doi: 10.1016/j.compedu.2020.104009

Sanaie, N., Vasli, P., Sedighi, L., and Sadeghi, B. (2019). Comparing the effect of lecture and Jigsaw teaching strategies on the nursing students' self-regulated learning and academic motivation: a quasiexperimental study. Nurse Educ. Today 79, 35-40. doi: 10.1016/j.nedt.2019. 05.022

Scherer, R., Howard, S. K., Tondeur, J., and Siddiq, F. (2021). Profiling teachers' readiness for online teaching and learning in higher education: who's ready? Comput. Hum. Behav. 118:106675. doi: 10.1016/j.chb.2020. 106675

Schoenmaker, T., Deng, M., and de Vries, T. J. (2020). Tailored teaching for specialized (para-)medical students - experience from incorporating a relevant genetic disease throughout a course of molecular cell biology. Front. Public Health 8:224. doi: 10.3389/fpubh.2020. 00224

Souza, P. P. C., and Lerner, U. H. (2019). Finding a toll on the route: the fate of osteoclast progenitors after toll-like receptor activation. Front. Immunol. 10:1663. doi: 10.3389/fimmu.2019.01663

Styers, M. L., van Zandt, P. A., and Hayden, K. L. (2018). Active learning in flipped life science courses promotes development of critical thinking skills. CBE Life Sci. Educ. 17:ar39. doi: 10.1187/cbe.1611-0332

Tuma, F., Nassar, A. K., Kamel, M. K., Knowlton, L. M., and Jawad, N. K. (2021). Students and faculty perception of distance medical education outcomes in resource-constrained system during COVID-19 pandemic. A 
cross-sectional study. Ann. Med. Surg. 62, 377-382. doi: 10.1016/j.amsu.2021. 01.073

Van Alten, D. C. D., Phielix, C., Jansen, J., and Kester, L. (2019). Effects of flipping the classroom on learning outcomes and satisfaction: a meta-analysis. Educ. Res. Rev. 28:100281. doi: 10.1016/j.edurev.2019. 05.003

Watermeyer, R., Crick, T., Knight, C., and Goodal, J. (2021). COVID-19 and digital disruption in UK universities: afflictions and affordances of emergency online migration. Higher Educ. 81, 623-641. doi: 10.1007/s10734-02000561-y
Conflict of Interest: The author declares that the research was conducted in the absence of any commercial or financial relationships that could be construed as a potential conflict of interest.

Copyright (c) 2021 de Vries. This is an open-access article distributed under the terms of the Creative Commons Attribution License (CC BY). The use, distribution or reproduction in other forums is permitted, provided the original author(s) and the copyright owner(s) are credited and that the original publication in this journal is cited, in accordance with accepted academic practice. No use, distribution or reproduction is permitted which does not comply with these terms. 